\title{
89. DATA REPORT: RESULTS OF GEOCHEMICAL WELL LOGGING IN THE JAPAN SEA, SITES 794, 796, AND 797, LEG 127 ${ }^{1}$
}

\author{
Elizabeth Lewis Pratson, ${ }^{2}$ Cristina Broglia, ${ }^{2}$ Ralph Schaar, ${ }^{3}$ \\ Jeffery A. Meredith, ${ }^{4}$ and Richard W. Murray ${ }^{5}$
}

\begin{abstract}
Geochemical well logs were recorded in the sediment sections of Holes 794B, 796B, and 797C of Leg 127, as well as in the basement section of Hole 797C. Corrections have been applied to these logs to account for variations in hole size, attenuation by drilling fluids, and drill-pipe effects. Oxide weight percentages have been calculated from the processed logs and compared to the available X-ray fluorescence (XRF) core measurements in the sediment section of Hole 794B and in the basement section of Hole 797C. In Hole 794B, reasonably good agreement between logs and core is exhibited; in the basement section of Hole 797C, agreement is excellent.
\end{abstract}

\section{INTRODUCTION}

To obtain a larger sample for studying the geology of the Japan Sea, the holes of Leg 127 were drilled in conjunction with those of Leg 128. The sites of the former were located in the basinal areas; those of the latter concentrated on the high-standing blocks. The main objectives were (1) to determine the age and nature of the basement of the Japan Sea, (2) to unravel the evolution of sediments in the region, (3) to assess the timing and events leading to the tectonic uplift and compression found along the eastern margin, and (4) to measure the present stress field in the region. Geochemical well logs can provide a continuous record of rock geochemistry, which is essential for interpreting the geology of the area.

Geochemical logging results from Holes 794B, 796B, and 797C (Fig. 1) are presented here. Holes 794B and 797C were drilled to reach basement. Hole 796B was drilled to determine the timing of the initiation of tectonic convergence in the area. The lithologies encountered at each of the holes drilled are summarized in Figure 2. Lithologies were dominated by (1) sands and siltstones rich in plant debris in the lower Miocene sequence, (2) siliceous and carbonate-rich claystones and volcanic tuffs in the middle Miocene, (3) claystones and porcellanites in the upper Miocene, (4) diatom oozes during the Pliocene, and (5) rhythmic light/dark sediments during the PliocenePleistocene (Shipboard Scientific Parties, Legs 127 and 128, 1990).

This report discusses the hole conditions and logging operations encountered at each hole logged with the geochemical tool, outlines the basic principles of the geochemical tools and explains the data processing techniques, and then presents the final oxide measurements that were calculated from logs and compares them to available XRF core measurements.

\section{DATA ACQUISITION}

\section{Site 794}

The original plan at Site 794 was to drill three holes, one using the advanced piston corer/extended core barrel (APC/XCB) to recover a

\footnotetext{
${ }^{1}$ Tamaki, K., Suyehiro, K., Allan, J., McWilliams, M., et al., 1990. Proc. ODP, Sci. Results, 127/128: College Station, TX (Ocean Drilling Program).

${ }^{2}$ Lamont-Doherty Geological Observatory of Columbia University, Palisades, NY 10964, U.S.A.

${ }^{3}$ Old York Road, Philadelphia, PA 19126, U.S.A.

${ }^{4}$ Chevron Oil Field Research Company, 1300 Beach Blvs., Box 466, La Habra, CA 90633-0446, U.S.A.

${ }^{5}$ Dept. of Geology and Geophysics, University of California, Berkeley, Berkeley, CA 94720 , U.S.A.
}

complete and relatively undisturbed sedimentary interval in the indurated sediments, a second to be cored from the total depth reached in the first hole to $20 \mathrm{~m}$ into hard basement rock, and a third, a reentry hole, to be drilled and cased to the total depth of the second hole and then deepened $100 \mathrm{~m}$ into basement.

Calm weather provided optimum drilling conditions for Hole 794A. The APC was used to $139.8 \mathrm{mbsf}$, where it was changed to the XCB, which reached 351.3 mbsf. Core recovery with the APC (100\%) was excellent, and with the XCB, good (Shipboard Scientific Party, 1990b). Hole 794B was drilled and spot-cored to a depth of $338.3 \mathrm{mbsf}$ and then continuously cored from 338.3 to $549.0 \mathrm{mbsf}$, with variable recovery $(0.5 \%-105 \%)$. Hard, fractured dolerites were encountered at $544 \mathrm{mbsf}$, which decreased drilling rates so significantly that drilling was terminated after $6 \mathrm{~m}$. Hole $794 \mathrm{C}$ had to be abandoned after the drill pipe stuck in a constriction at the bottom of the hole.

In preparation for logging Hole 794B, a wiper trip was made to 55 mbsf, and the hole was flushed with high viscosity mud and then conditioned with $\mathrm{KCl}$-inhibited drilling mud. As a result of good hole conditions, three successful openhole logging runs were made from 536 to 100 mbsf with the quad-combo tool string, which includes the sonic, density, resistivity, and neutron porosity tools, the geochemical tool string, and the formation microscanner (FMS, trademark of Schlumberger). The upper $100 \mathrm{~m}$ of the hole was logged through pipe with the geochemical tool string. Electrical and acoustical tools do not record data through pipe, because electrical currents and sound waves cannot propagate through steel and into the formation. Neutrons and gamma rays, however, can pass and be detected through pipe; thus, geochemical and radioactive logs can still be recorded, but the signal detected from the formation is greatly attenuated, which decreases the signal-to-noise ratio. The through-pipe sections of logs from Hole 794B were processed and are presented; the data were not, however, of as high quality as those of the lower, open-hole sections.

\section{Site 796}

Two holes were planned for Site 796, one an APC/XCB hole through the indurated sediments, and the other a rotary core barrel (RCB) hole, beginning at the total depth of the previous hole. In Hole 796A the APC was used to 51 mbsf, where a hard layer was encountered. The XCB was then used to reach $242.9 \mathrm{mbsf}$. Recovery was excellent in the upper $51 \mathrm{~m}$ of the hole $(100 \%)$ with the APC, and good $(40 \%)$ in the lower, XCB portion of the hole. Hole 796B was washed to $30.2 \mathrm{mbsf}$, cored from 30.2 to $97.9 \mathrm{mbsf}$, washed to $243.0 \mathrm{mbsf}$, and then continuously cored from 243.0 to $464.9 \mathrm{mbsf}$. Recovery in the cored interval was highly variable $(0 \%-96 \%)$, and the hole was in poor condition (Shipboard Scientific Party, 1990c). 


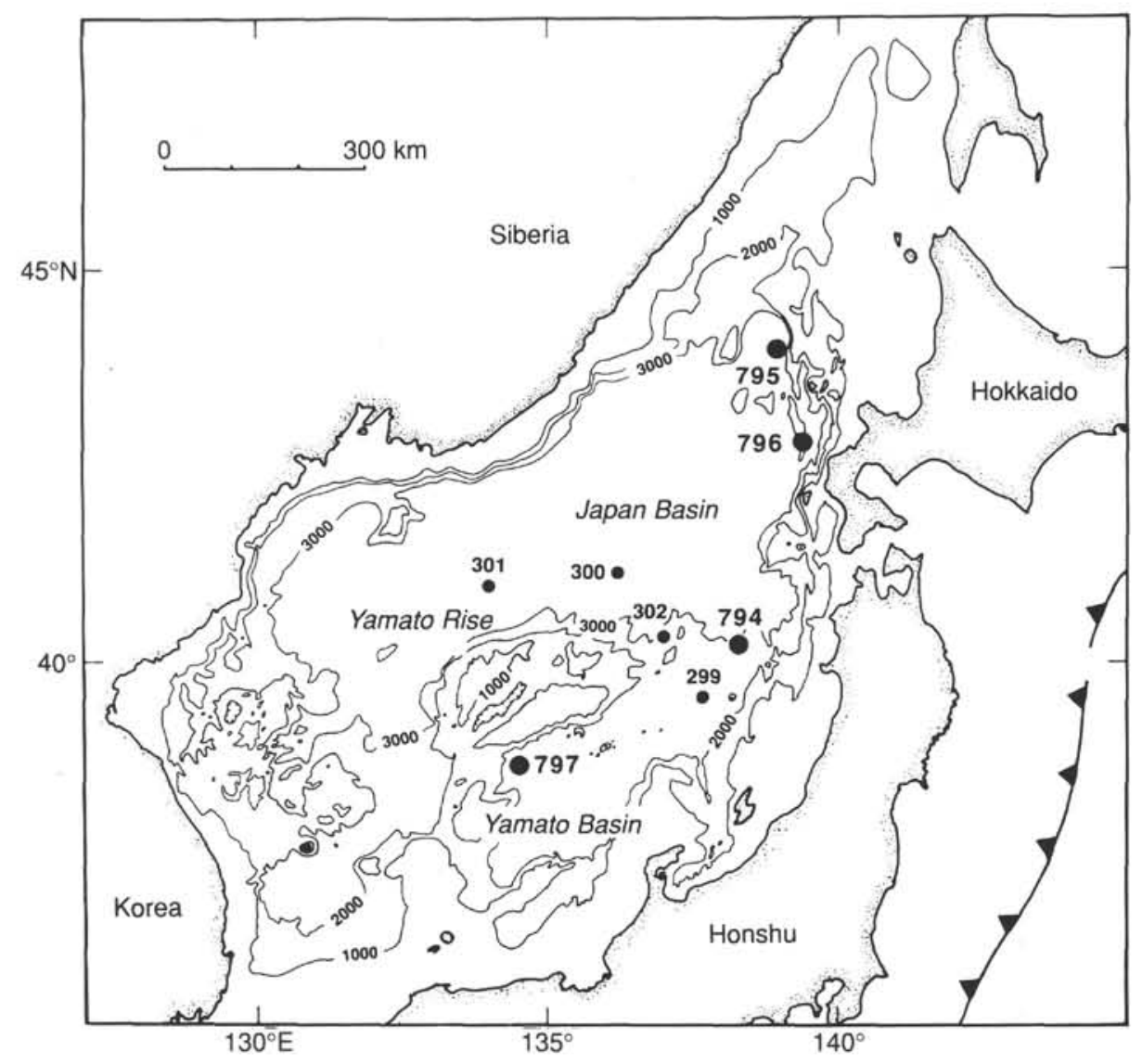

Figure 1. Map of the Japan Sea showing the location of the sites logged with the geochemical tool (Sites 794, 796, and 797 during ODP Leg 127; Tamaki et al., 1990a).

To prepare for logging, pipe was raised to $100 \mathrm{mbsf}$, and the hole was filled with a $\mathrm{KCl}$ solution. Because of the poor hole conditions indicated during drilling, the first tool string, a quad-combo, did not include the radioactive, neutron porosity tool. The run was successful, logging open hole from 344.7 to $100 \mathrm{mbsf}$ and through pipe from $101 \mathrm{mbsf}$ to the top of the hole. The tool string was run again, this time with the neutron porosity tools attached, and it recorded data open hole from 330 to 90 mbsf. The third logging pass ran the FMS open hole from 334 to $79.5 \mathrm{mbsf}$. Finally, the geochemical tool string was run through both the open hole (329-102 mbsf) and pipe (102-0 mbsf) portions of the hole.

\section{Site 797}

Drilling plans called for two holes at Site 797, again one APC/XCB hole into sediments, and another a reentry RCB hole for deeper scientific objectives. Because the first core in Hole 797A missed the mud line, Hole 797B was spudded. APC coring was used in Hole 797B to 175.9 mbsf with excellent recovery. At 175.9 mbsf, $\mathrm{XCB}$ coring was used, with variable but nevertheless good recovery to $495.7 \mathrm{mbsf}$. After the reentry cone and the 16-in. casing were set, Hole $797 \mathrm{C}$ was washed to $484 \mathrm{mbsf}$ and was cored with the RCB to 800 mbsf. Basalt was first encountered in Hole 797C at 554 mbsf, below which sediments and basalts were interlayered (Shipboard Scientific Party, 1990d).

A wiper trip encountered resistance at $650 \mathrm{mbsf}$, thus the hole was reamed and flushed with mud. Pipe was set at $80 \mathrm{mbsf}$. The FMS string was run from 83.2 to $516 \mathrm{mbsf}$, where it hit an impassable blockage of tuff layers. The quad-combo string was then run from 0 to $633 \mathrm{mbsf}$. Next, in an attempt to log the lower portion of the hole with the FMS, pipe was lowered to total depth to knock out bridges and then was pulled up to $543 \mathrm{mbsf}$; however, the FMS still could not pass below 566 mbsf. Because of poor hole conditions and the risk of losing the geochemical tool string, pipe was finally set at $623 \mathrm{mbsf}$, and the geochemical combination logged through pipe. A final, successful attempt was made to log the lower portion of the hole with the FMS, this time using the side-entry sub (SES), and data were recorded from 485 to 605 mbsf. Logging operations concluded with the successful run of the borehole televiewer from 603 to $549 \mathrm{mbsf}$.

\section{GEOCHEMICAL TOOL STRING}

The geochemical logging tool string (GLT) consists of four separate logging tools: the natural gamma-ray tool (NGT), the compensated neutron tool (CNT), the aluminum activation clay tool (AACT), and the gamma-ray spectrometry tool (GST; Fig. 3) (GLT, NGT, CNT, AACT, and GST are trademarks of Schlumberger). The NGT, located at the top of the tool string, measures the naturally occurring radionuclides thorium (Th), uranium (U), and potassium (K) before the formation is irradiated by the nuclear sources mounted on following tools. The compensated neutron tool, placed below the natural gamma-ray tool, carries a low-energy neutron source $\left({ }^{252} \mathrm{Cf}\right)$ that activates the aluminum atoms in the formation. The AACT tool, a modified NGT, follows the ${ }^{252} \mathrm{Cf}$ source and measures the activated gamma rays in the formation. By combining this measurement with the previous NGT measurement, background radiation can be subtracted out and a reading of formation Al can be obtained (Scott and Smith, 1973). The GST, located at the bottom of the string, carries both a pulsed-neutron generator for bombarding the borehole and formation and a $\mathrm{NaI}$ scintillation counter for measuring the spectrum 


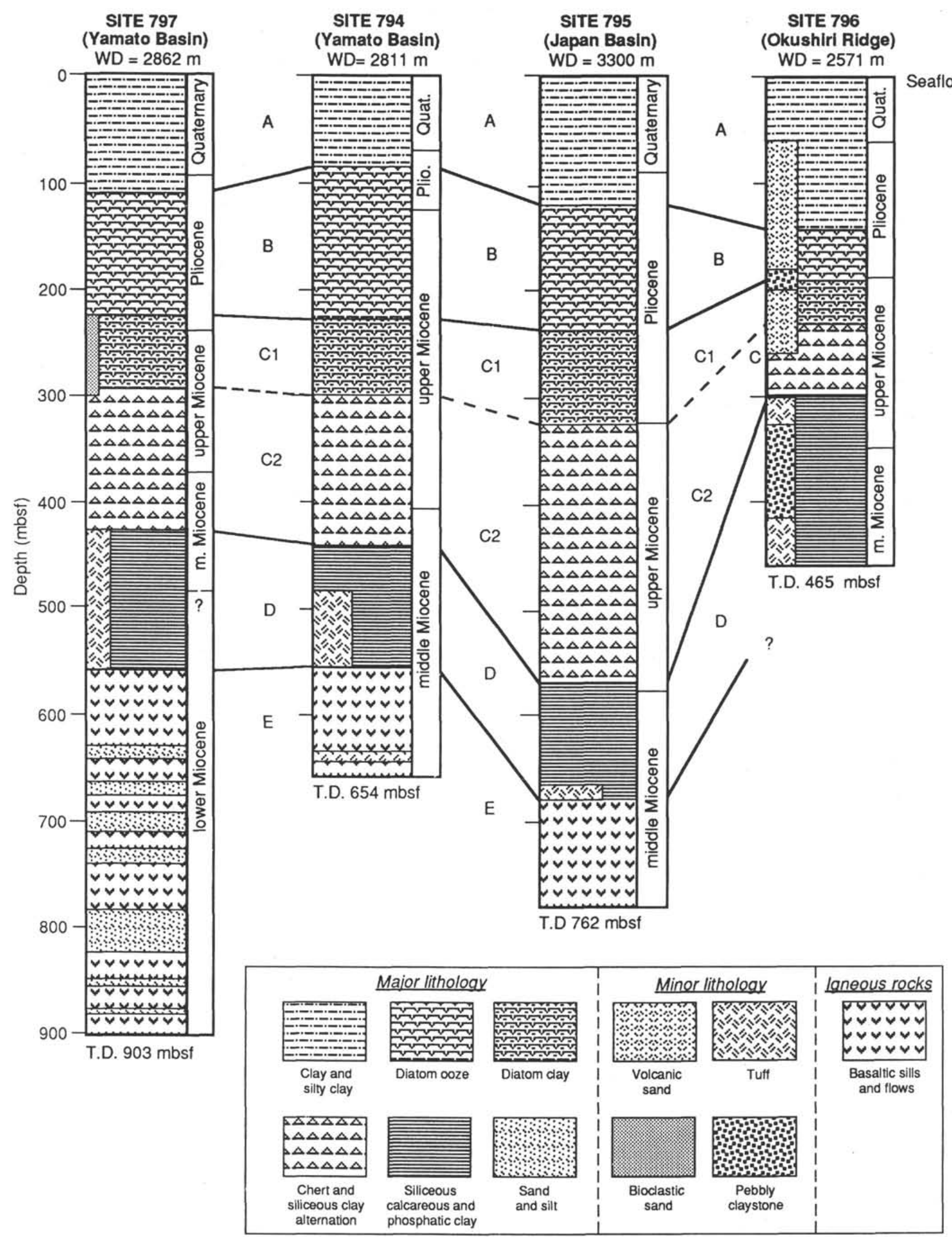

Figure 2. Summary of the major lithofacies encountered at the Leg 127 sites (Tamaki et al., 1990). 
TCCB

NGT

CNT-G

AACT

GST
Telemetry cartridge

Natural gamma-ray tool: measures naturally radioactive elements $\mathrm{Th}, \mathrm{U}$, and $\mathrm{K}$.

Dual-porosity compensated neutron tool: measures neutron porosity in the thermal and epithermal energy ranges.

— Thermal detectors

$\longleftarrow{ }^{252} \mathrm{Cf}$ source

Epithermal detectors

Aluminum activation clay tool: Measures aluminum activation and natural count rates as it passes the formation activated by ${ }^{252} \mathrm{Cf}$ source.

Gamma-ray spectrometry tool: Measures concentration of $\mathrm{Ca}, \mathrm{Si}, \mathrm{Fe}, \mathrm{S}, \mathrm{Gd}, \mathrm{Ti}, \mathrm{H}, \mathrm{Cl}$ and formation capture cross-section.

\section{Boron sleeve - 3.75 in.}

Neutron accelerator

Figure 3. Schematic drawing of the geochemical tool string used by the Ocean Drilling Program. 
of gamma rays generated by neutron capture reactions. Because each of the elements in the formation is characterized by a unique spectral signature, it is possible to derive the contribution (or yield) of the major elements silicon ( $\mathrm{Si})$, iron ( $\mathrm{Fe})$, calcium $(\mathrm{Ca})$, titanium $(\mathrm{Ti})$, sulfur $(\mathrm{S})$, gadolinium $(\mathrm{Gd})$, and potassium $(\mathrm{K})$ to the measured spectrum and, in turn, to estimate their abundances in the formation. The GST also measures hydrogen $(\mathrm{H})$ and chlorine $(\mathrm{Cl})$ in the borehole and formation; however, these elements are not used when determining rock geochemistry.

The only major rock-forming elements not measured by the GST are magnesium $(\mathrm{Mg})$ and sodium $(\mathrm{Na})$; the neutron-capture cross sections of these elements are too small to be detected by the GST. One can estimate their abundances roughly by using the photoelectric factor (PEF), measured by the lithodensity tool. The measured PEF is compared to a calculated PEF, derived by summing the PEF values expected from all the other measured elements. The difference between the measured and calculated PEF is attributed to any element left over in the formation, mainly $\mathrm{Mg}$ and $\mathrm{Na}$. This calculation was performed at the three holes, but it yielded zero percent $\mathrm{Mg}$ throughout, except for a few erratic spikes. As this was interpreted to be incorrect, the $\mathrm{Mg}$ calculation was omitted at each hole.

\section{DATA REDUCTION}

The well-logging data from the Schlumberger tools are transmitted digitally up a wireline and then are recorded and processed on board the JOIDES Resolution in the Schlumberger Cyber service unit (CSU). Results from the CSU processing are made available as "field $\operatorname{logs}$ " for initial interpretation at sea. Subsequent reprocessing is necessary to correct the data for the effects of logging conditions, fluids added to the well, logging speed, and pipe attenuation. Processing of the spectrometry data is required to transform the relative elemental yields into oxide weight fractions.

A set of log interpretation programs written by Schlumberger is used to process the data. The processing steps are summarized as follows.

\section{Reconstruction of Relative Elemental Yields from Recorded Spectral Data}

This first step compares the measured spectra from the geochemical spectrometry tool with a series of standard spectra to determine the relative contribution, or yield, of each element, using a least-squares method. Six elemental standards-silicon $(\mathrm{Si})$, iron $(\mathrm{Fe})$, calcium $(\mathrm{Ca})$, sulfur $(\mathrm{S})$, chlorine $(\mathrm{Cl})$, and hydrogen $(\mathrm{H})$ - are used to produce the yields at sea; three additional standards - titanium (Ti), gadolinium (Gd), and potassium $(\mathrm{K})$ - are included in the shore-based processing. Although these additional elements often occur in low concentrations in the formation, their large neutron-capture cross sections enable them to make a large contribution to the measured spectra. The capture cross section of $\mathrm{Gd}$, for instance, is 49,000 barns; that of $\mathrm{Si}$, only 0.16 barns (Hertzog et al., 1987). Gd, therefore, although occurring in small abundances in the formation, is included when calculating to obtain a best-fit of the measured with the standard spectra.

Because ODP logging conditions are not as ideal as those in which the Schlumberger tools are usually run, the standard processing techniques have been modified. We have found, for instance, that better results are obtained if the $\mathrm{K}$ standard is not included in this analysis, as $\mathrm{K}$ occurs in concentrations below the resolution of the tool and including it might cause noise in all of the other yields. The natural gamma-ray tool, which is run on each logging string, provides a more accurate measurement of $\mathrm{K}$ and, therefore, is used as an input in the geochemical processing.

The through-pipe iron yield at each of the holes was corrected for the effects of iron in the drill pipe and bottom hole assembly (BHA) by applying the appropriate offset for each pipe thickness. Pipe joints in Hole $797 \mathrm{C}$ were removed from the iron yield by interpolating between points above and below the pipe joint, thus invoking a straight line, rather than a spike, as was observed in the original field yields (Shipboard Scientific Party, 1990d). This is the only method of accounting for pipe joints, because we do not yet have a method for quantifying the amount of signal caused by the presence of the pipe and BHA.

\section{Depth Shifting}

The depths of each logging run are shifted to match those of a chosen reference run. A total gamma-ray curve from the natural gamma-ray tool, run on each tool string, is generally selected as the reference curve on the basis of low cable tension. At Holes 794B and $796 \mathrm{~B}$, the logs were depth-referenced to the quad-combo tool string logging runs. At Hole 797C, the geochemical run was chosen instead, because it was the longest logging pass, and it was run through pipe, where minimal sticking occurred.

\section{Calculation of Total Radioactivity and Th, $U$, and $K$ Concentrations}

Using the counts in five spectral windows from the natural gammaray tool (Lock and Hoyer, 1971), one next calculates the total natural gamma-ray radiation in the formation as well as concentrations of Th, $\mathrm{U}$, and $\mathrm{K}$. This procedure resembles the one performed at sea, except that corrections for changes in hole size are made. A Kalman filter (Ruckebusch, 1983) is used to correct for statistical errors in the logs, which often create erroneous negative readings and anti-correlations, especially between Th and U. At each measured depth interval, a calculation and a correction are performed for the $\mathrm{K}$ contained in the mud. This $\mathrm{K}$ correction is particularly useful for ODP holes as $\mathrm{KCl}$ is routinely added, but one must remember that dilution makes it difficult to know exactly how much $\mathrm{K}$ is actually in the borehole. The outputs of this program are $\mathrm{K}$ (wet vol\%), $\mathrm{U}$ (ppm), and Th (ppm), along with total and computed gamma-ray curves $(\mathrm{Th}+\mathrm{K})$. As an NGT is included on each tool string, the processing is performed for each pass.

The best reprocessed pass, that is, the openhole pass having the slowest cable speed and, therefore, the best counting statistics, is displayed in this report. The final gamma-ray passes for Holes 794B and 796B came from the geochemical tool string. The final pass for Hole $797 \mathrm{C}$ was taken primarily from the openhole quad-combo tool string with through-pipe geochemical logs spliced in the portions where no openhole data were recorded.

\section{Calculation of Al Concentration}

Using four energy windows from the AACT, the fourth routine produces an $\mathrm{Al}$ curve, while simultaneously correcting for borehole fluid and formation neutron-capture cross sections, formation slowing-down length, and borehole size. Porosity and density logs are used to convert the wet volume percentage of $\mathrm{K}$ and $\mathrm{Al}$ curves to dry weight percent. For each of the holes, the density curves agreed closely with the core measurements, but the porosity curves from both the sonic and neutron tools deviated from the core measurements. Therefore, a porosity curve was calculated from the density curve in each hole.

A correction was also made for $\mathrm{Si}$ interference with $\mathrm{Al}$. Si can become activated by the ${ }^{252} \mathrm{Cf}$ source, causing a reaction that produces the aluminum isotope, ${ }^{28} \mathrm{Al}$ (Hertzog et al., 1987). The program uses the Si yield from the GST to determine the background correction for $\mathrm{Si}$. It produces dry weight percentages of $\mathrm{Al}$ and $\mathrm{K}$, which are used to calculate and normalize the remaining elements.

\section{Normalization of Al and $\mathrm{K}$ With Elemental Yields To Calculate the Elemental Weight Fractions}

The next routine takes the dry weight percentages of $\mathrm{Al}$ and $\mathrm{K}$ and normalizes them with the reconstructed yields to obtain dry weight percentages of the elements. It uses the following relationship: 


$$
W t_{\mathrm{i}}=F Y_{\mathrm{i}} / S_{\mathrm{i}}
$$

where $W t_{i}=$ absolute elemental concentration, $F=$ normalization factor, $Y_{\mathrm{i}}=$ relative elemental yield, and $S_{\mathrm{i}}=$ tool spectral sensitivity. The normalization factor, $F$, is a calibration factor determined at each depth to account for the $\mathrm{C}$ and $\mathrm{O}$ associated with each element. Because the sum of the oxides in a rock is $100 \%, F$ is given by:

$$
F\left[\Sigma X_{i}\left(Y_{\mathrm{i}} / S_{\mathrm{i}}\right)\right]+X_{\mathrm{K}} W t_{\mathrm{K}}+X_{\mathrm{Al}} W t_{\mathrm{Al}}=100
$$

where $X_{\mathrm{i}}=$ dry wt $\%$ of oxide or carbonate/dry wt $\%$ of element $i, Y_{\mathrm{i}}=$ fraction of spectra attributed to element $i ; S_{\mathrm{i}}=$ sensitivity factor, $X_{\mathrm{K}}=$ dry $w t \%$ of oxide of element $\mathrm{K} /$ dry $w t \%$ of $\mathrm{K} ; W t_{\mathrm{K}}=$ dry $w \mathrm{t} \% \mathrm{~K}, X_{\mathrm{Al}}$ $=$ dry $\mathrm{wt} \%$ of oxide of element $\mathrm{Al} / \mathrm{dry} \mathrm{wt} \%$ of $\mathrm{Al}$; and $W t_{\mathrm{Al}}=$ dry $\mathrm{wt} \%$ Al. The sensitivity factor, $S_{\mathrm{i}}$, is a tool constant, measured in the laboratory, that depends on the capture cross section of each element measured by the geochemical tool (Hertzog et al., 1987).

Sulfur is left out of this normalization process, because it gives an erroneously high sulfur content $(5 \%-15 \%$, which is much higher than in core [Tamaki et al., 1990b, 1990c, 1990d]). When trying to obtain best-fit spectra from the induced GST (Step 1), it is important to include the S yield, because the tool sees minor amounts of sulfur in the water when logging open hole and in the steel when logging through pipe.

\section{Calculation of Oxide Percentages}

Dry weight percentages of the main oxides are calculated by multiplying the percentage of each element by its associated oxide factor (Table 1), which is the same factor assumed in the normalization (Step 5).

Table 1. Oxide/carbonate factors used to normalize elements to $100 \%$ and to convert elements to oxides/carbonates.

\begin{tabular}{clc}
\hline Element & Oxide/carbonate & Conversion factor \\
\hline $\mathrm{Si}$ & $\mathrm{SiO}_{2}$ & 2.139 \\
$\mathrm{Ca}$ & $\mathrm{CaO}$ & 1.399 \\
$\mathrm{Fe}$ & $\mathrm{FeO}^{*}$ (total iron) & 1.358 \\
$\mathrm{~K}$ & $\mathrm{~K}_{2} \mathrm{O}$ & 1.205 \\
$\mathrm{Ti}$ & $\mathrm{TiO}_{2}$ & 1.668 \\
$\mathrm{Al}$ & $\mathrm{Al}_{2} \mathrm{O}_{3}$ & 1.899 \\
\hline
\end{tabular}

\section{RESULTS}

\section{Site 794}

The processed natural gamma-ray data from the geochemical tool string recorded at Hole 794B are shown in Figure 4. The upper $100 \mathrm{~m}$ of through-pipe logs have been corrected for pipe attenuation, and zones of erroneous data have been removed, which produced the blank spots on the logs. The calculation of Th, $\mathrm{U}$, and $\mathrm{K}$ represents an improvement over the shipboard results; for instance, the $\mathrm{K} \log$, which was negative in the field logs (Shipboard Scientific Party, $1990 \mathrm{~b}$ ) because of an overcorrection for $\mathrm{KCl}$, is now positive.

These natural gamma-ray logs are useful for delineating most of the major unit boundaries of the hole. Unit I was recorded through pipe. Because it is difficult to tell if all of the pipe attenuation was accounted for, any lithologic interpretation of the data in this zone should be done with caution. The two subunits of Unit II are differentiated on the total gamma-ray curve by a gradual increase in radioactivity in Subunit IIB, primarily due to the $\mathrm{K}$ and Th compo- nents. This increase indicates the transition from diatom ooze in Subunit IIA to diatom clay in Subunit IIB. A sharp increase on the total gamma-ray curve, resulting mostly from $\mathrm{K}$ and Th contents, marks the top of the claystones of Unit III. A decrease in value with an increase in variation in the total gamma-ray content, possibly related to the cement lenses of diagenetic minerals described in core, characterizes Subunit IIIB. At about 395 mbsf, the variation lessens and the $\mathrm{U}$ increases. This corresponds to the change in $\mathrm{Si}$ phase from opal-CT to quartz. The increase in $\mathrm{K}$ at $450 \mathrm{mbsf}$ suggests instead an increase in clay. Unit IV, a tuff, is marked on the natural gamma-ray logs by a clear decrease in the total signal, with each component showing a different general character. For example, the $\mathrm{K}$ increases with depth, the Th decreases with depth, while the U displays values close to zero throughout the unit; this suggests more K-rich clay minerals with depth in Unit IV. The very top of the claystones marking Unit V can be seen as a sharp increase on all gamma-ray logs at $515 \mathrm{mbsf}, 5.6 \mathrm{~m}$ higher than described in the cores.

The oxide weight fractions for Hole 794B, along with XRF measurements (R.W. Murray, pers. comm., 1992), are shown in Figure 5. The log intervals where no data are shown result from erroneous data recorded through pipe. The two subunits of Unit II are distinguished on the $\mathrm{Al}, \mathrm{K}$, and $\mathrm{Si}$ oxide logs. $\mathrm{Al}_{2} \mathrm{O}_{3}$ and $\mathrm{K}_{2} \mathrm{O}$ increase in Subunit IIB, mirroring a decrease in $\mathrm{SiO}_{2}$ and suggesting an increase in clay content at the expense of diatoms in Subunit IIB. The top of Unit III is marked by an increase in $\mathrm{SiO}_{2}$ and $\mathrm{K}_{2} \mathrm{O}$ and a decrease in $\mathrm{Al}_{2} \mathrm{O}_{3}$, while a decrease in $\mathrm{Al}_{2} \mathrm{O}_{3}$ delineates the top of Subunit IIIB. A decrease in $\mathrm{SiO}_{2}$ content coupled with an increase in $\mathrm{K}_{2} \mathrm{O}$ and $\mathrm{Al}_{2} \mathrm{O}_{3}$ indicate an increase in clay content at the base of Subunit IIIB. The tuff and claystone of Unit IV is clearly discriminated by an increase in $\mathrm{Al}_{2} \mathrm{O}_{3}, \mathrm{FeO}^{*}$ (total iron), $\mathrm{K}_{2} \mathrm{O}$ and $\mathrm{Gd}$. The top of Unit $\mathrm{V}$ is indicated on the oxide logs by an increase in $\mathrm{SiO}_{2}$ and $\mathrm{K}_{2} \mathrm{O}$ and by a decrease in $\mathrm{Al}_{2} \mathrm{O}_{3}$.

Discrepancies between the core and log values are significant. It is clear in the upper $100 \mathrm{~m}$ of Unit $\mathrm{I}$ that the $\mathrm{Al}$ and $\mathrm{K}$ correction for pipe attenuation was not sufficient; as a result, $\mathrm{Al}_{2} \mathrm{O}_{3}$ and $\mathrm{K}_{2} \mathrm{O}$ weight fractions are too low, and because of the normalization process, the other oxides are too high. The $\mathrm{Al}$ curve is too high throughout Unit II, yet more accurate below Unit II. This discrepancy might be the result of a concentration of the mud used to wash out the hole, or to the rock samples for $\mathrm{XRF}$ being preferentially selected. The $\mathrm{K}_{2} \mathrm{O} \log$ is high throughout the openhole section of the logs. Again, this may be due to interference caused by the $\mathrm{KCl}$ added to the hole or to preferentially clay-free sampling. The other oxides agree well with the cores, but the normalization process dictates that each log affects all other logs.

\section{Site 796}

The processed natural gamma-ray logs from Hole 796B are displayed in Figure 6. The upper $100 \mathrm{~m}$ were logged through pipe, and although corrections were made for attenuation in the through-pipe interval, zones of erroneous data existed and have been removed.

In this hole, subtle changes in the natural gamma-ray logs mark the major unit boundaries. Unit II is distinguished by an increase in gamma-ray content, primarily due to $\mathrm{K}$, possibly reflecting an increase in clay content in this unit. The claystone and sandstone lithology of Unit III is characterized by an increase in variability, similar to the character seen in Unit III of the natural gamma-ray logs of Hole 794B. A decrease in variability and an increase in Th mark the tuff described in Unit IV.

The oxide weight fractions are displayed in Figure 7. Unit II is differentiated from Unit I at $136 \mathrm{mbsf}$ ( $10.2 \mathrm{~m}$ shallower than the core, where it was at $146.2 \mathrm{~m}$ ) by decreasing $\mathrm{Al}_{2} \mathrm{O}_{3}$ and slightly decreasing $\mathrm{SiO}_{2}$. Unit III is characterized by an increase at 209 mbsf in $\mathrm{Al}_{2} \mathrm{O}_{3}$, $\mathrm{FeO}^{*}$, and $\mathrm{SiO}_{2}$, which roughly coincides with the diagenetic change in Si from opal-A to opal-CT. As with Unit IV of Hole 794B, tuff is characterized in the geochemical logs by a decrease in $\mathrm{K}_{2} \mathrm{O}$ content. 


\section{Site 797}

Figure 8 displays the processed natural gamma-ray logs from Hole 797C. To maximize openhole data and still present the complete logged interval, the logs presented consist of through-pipe logs from the geochemical tool string in the intervals from 0 to $80.6 \mathrm{mbsf}$ and from 480 to $629 \mathrm{mbsf}$ and of openhole logs from the quad-combo tool string in the interval from 80.6 to $480 \mathrm{mbsf}$. The evenly spaced spikes in the upper $80 \mathrm{~m}$ represent pipe joints that have not been removed from the gamma-ray curves, and as such they should not be interpreted as lithologic changes. Because the boundary between Subunits IA and IB occurs at roughly the same depth where the through-pipe data were spliced with the openhole data, the change in character of the logs at this boundary must be interpreted with caution. The increase in diatom content described in Unit II at approximately 185 mbsf in the core (Shipboard Scientific Party, 1990d) is marked on the total gamma-ray curve by a slight decrease in value, suggesting a decrease in clay content at the expense of diatoms. Unit III is distinguished in the cores by a significant decrease in diatom content, reflected in the logs by higher gamma-ray value. A significant increase in radioactivity occurs at $299 \mathrm{mbsf}$, the top of the claystones of Unit IV and the transition from opal-A to opal-CT. Gamma-ray values decrease and show more variations in Subunit IVB. A renewed gamma-ray content, primarily due to $\mathrm{K}$, marks the top of Unit V. The spikes at the bottom half of this unit result from activation by the ${ }^{252} \mathrm{Cf}$ source of the AACT and yo-yoing of the logging tool during recording. We were unable to correct these spikes; however, an interpolation was done to eliminate spikes on the $\mathrm{K}$ curve to perform the normalization process for elemental calculation.

The final oxide weight fractions are presented in Figure 9, along with XRF analyses performed on board the ship (Shipboard Scientific Party, 1990d). The Al curve tracks the K curve, thus indicating the clay vs. diatom contents of Units I, II, and III. The boundary between Units IV and $\mathrm{V}$ is distinguished by a sharp increase in $\mathrm{Al}_{2} \mathrm{O}_{3}$ and a decrease in $\mathrm{SiO}_{2}$ at 427 mbsf, suggesting an increase in clay content at this depth. This boundary also marks the change in $\mathrm{Si}$ from opal-CT to quartz. XRF samples were taken in the igneous section of Hole 797C and show excellent correlation with the logs.

\section{CONCLUSIONS}

The reprocessing of natural gamma-ray logs improves the data calculated in the field by incorporating hole size corrections and better calibration of Th, U, and K. Geochemical logs can be converted to elemental and oxide measurements, which compare well with core data. When core data are missing, the reprocessed logs represent an invaluable data set from which to interpret lithology. The general trends of $\mathrm{SiO}_{2}, \mathrm{Al}_{2} \mathrm{O}_{3}$ and $\mathrm{K}_{2} \mathrm{O}$ were found to be particularly useful in tracing relative increases or decreases in diatom vs. clay content, because the diatom-rich zones are high in $\mathrm{SiO}_{2}$ and low in $\mathrm{Al}_{2} \mathrm{O}_{3}$ and $\mathrm{K}_{2} \mathrm{O}$. The total gamma-ray log has the potential to be an excellent tool for well-towell correlation, as witnessed by its ability to distinguish the boundary between opal-A and opal-CT in each of the wells, the boundary between opal-CT and quartz in Holes 794B and 797C, and the similarities in log character seen in the lower portion of each opal-CT unit (Subunit IIIB of Hole 794B and Subunit IVB of Hole 797C).

\section{ACKNOWLEDGMENTS}

The first author acknowledges James Bristow for all his help in unraveling some of the problems encountered while processing the geochemical log data; his quest to improve the processing really helped us here at the Borehole Research Group. All of us would like to thank Jennifer Tivy for her help and review.

\section{REFERENCES}

Hertzog, R., Colson, L., et al., 1987. Geochemical logging with spectrometry tools. Soc. Pet. Engrs. Pap., 16792, Dallas, TX.

Lock, G. A., and Hoyer, W. A., 1971. Natural gamma-ray spectral logging. The Log Analyst, 12(5):3-9.

Ruckebusch, G., 1983. A Kalman filtering approach to natural gamma ray spectroscopy in well logging. IEEE Trans., 372-380.

Scott, H. D., and Smith, M. P., 1973. The aluminum activation log. The Log Analyst, 14(5):3-12.

Shipboard Scientific Party, 1990a. Background, objectives, and principal results. In Tamaki, K., Pisciotto, K. A., Allan, J., et al., Proc. ODP. Init. Repts., 127: College Station, TX (Ocean Drilling Program), 5-23.

Shipboard Scientific Party, 1990b. Site 794. In Tamaki, K., Pisciotto, K. A., Allan, J., et al., Proc. ODP, Init. Repts., 127: College Station, TX (Ocean Drilling Program), 71-165.

Shipboard Scientific Party, 1990c. Site 796. In Tamaki, K., Pisciotto, K.A., Allan, J., et al., Proc. ODP, Init. Repts., 127: College Station, TX (Ocean Drilling Program), 247-322.

Shipboard Scientific Party, 1990d. Site 797. In Tamaki, K., Pisciotto, K. A., Allan, J., et al., Proc. ODP, Init. Repts., 127: College Station, TX (Ocean Drilling Program), 323-411.

Shipboard Scientific Parties, Legs 127 and 128, 1990. Evolution of the Japan Sea. Nature, 346(6279) 18-20.

Tamaki, K., Pisciotto, K. A., Allan, J., et al., 1990. Proc. ODP, Init. Reports, 127: College Station, TX (Ocean Drilling Program).

Date of initial receipt: 18 March 1991

Date of acceptance: 29 August 1991

Ms 127/128B-223 
崖

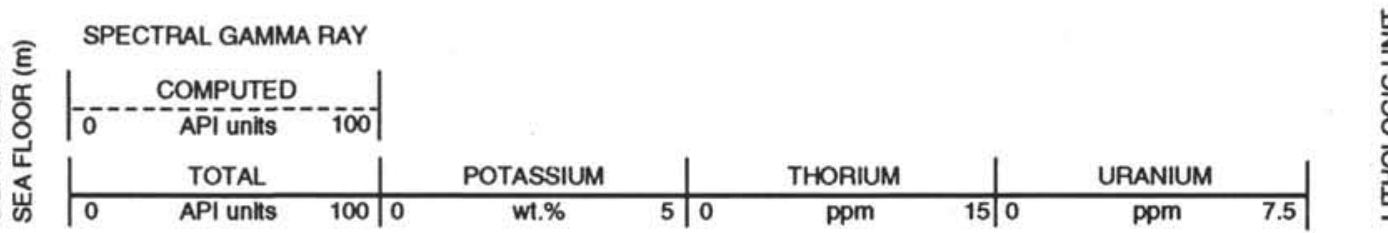

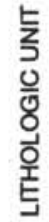

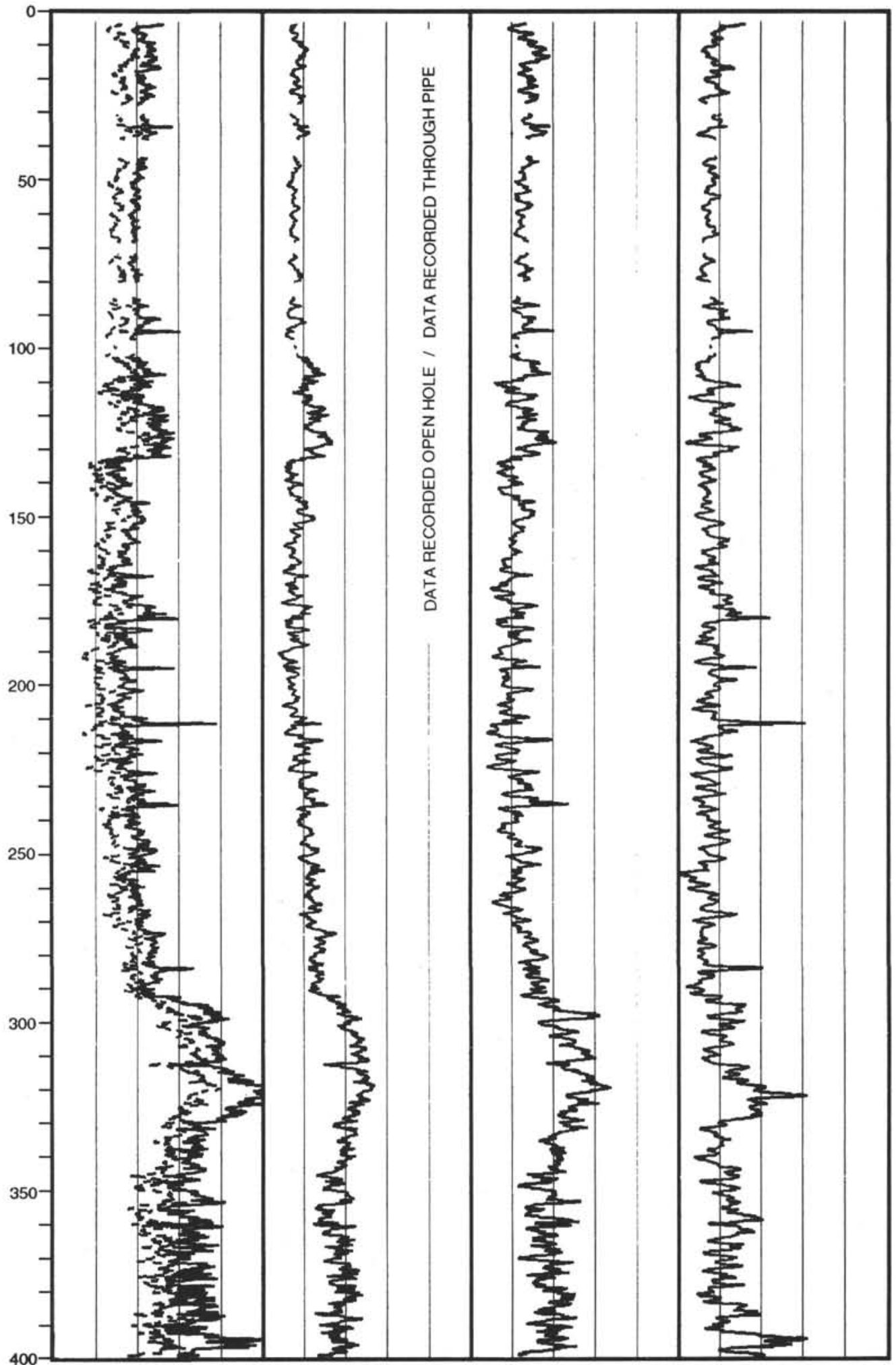

IA

IIA

Figure 4. Processed natural gamma-ray data at Hole 794B. 

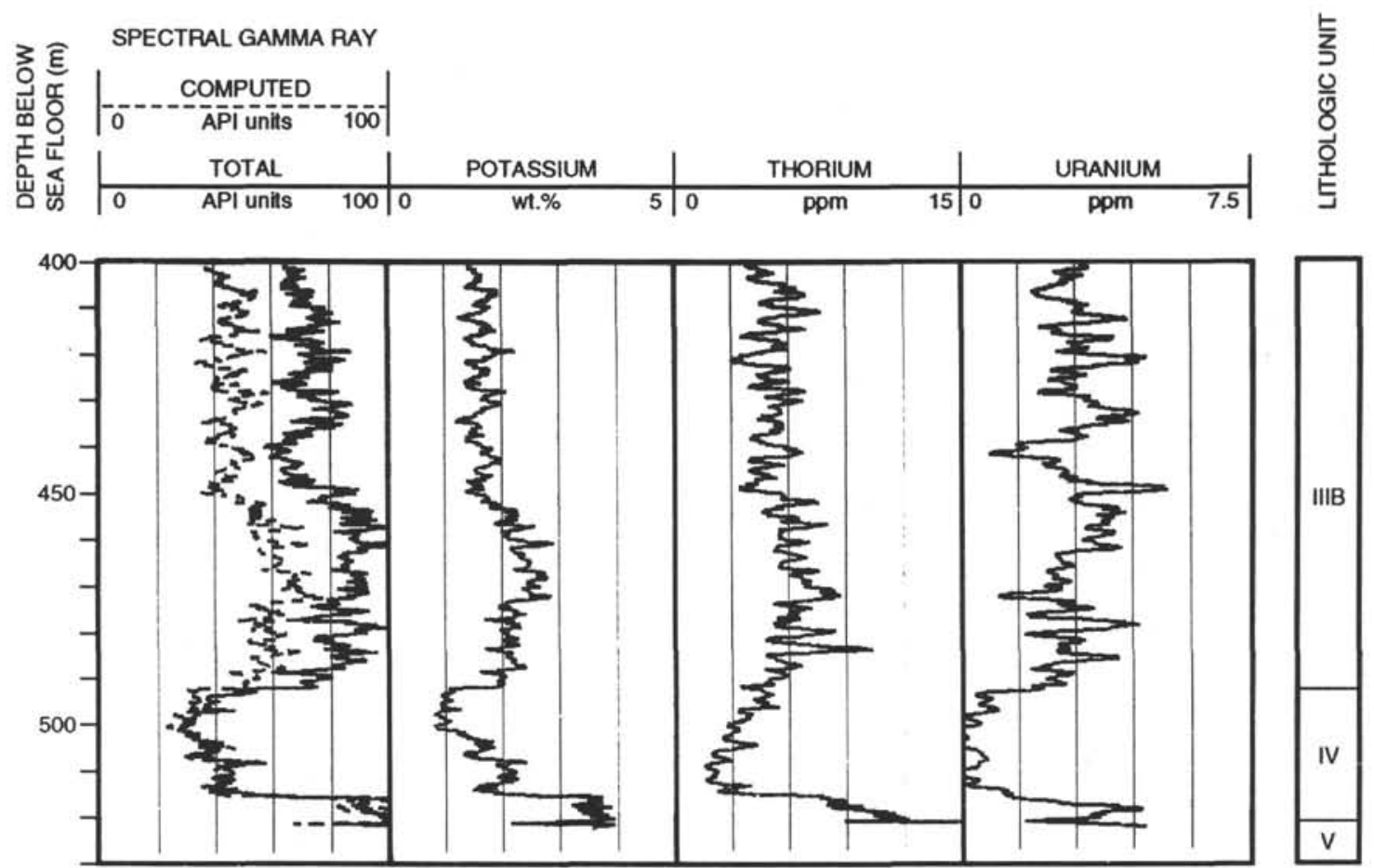

Hole 794B: legend of lithologic units

Unit IA. Clay and silty ashy clay

Unit IB. Clay and silty clay

Unit IIA. Diatom ooze and clayey diatom ooze

Unit IIB. Diatomaceous clay

Unit IIIA. Clay and siliceous claystone

Unit IIIB. Claystone

Unit IV. Tuff and claystone

Unit V. Claystone, silty clay, and calcareous claystone

Unit VI. Tuff overlain by tuffaceous silty claystone

Figure 4 (continued). 
공
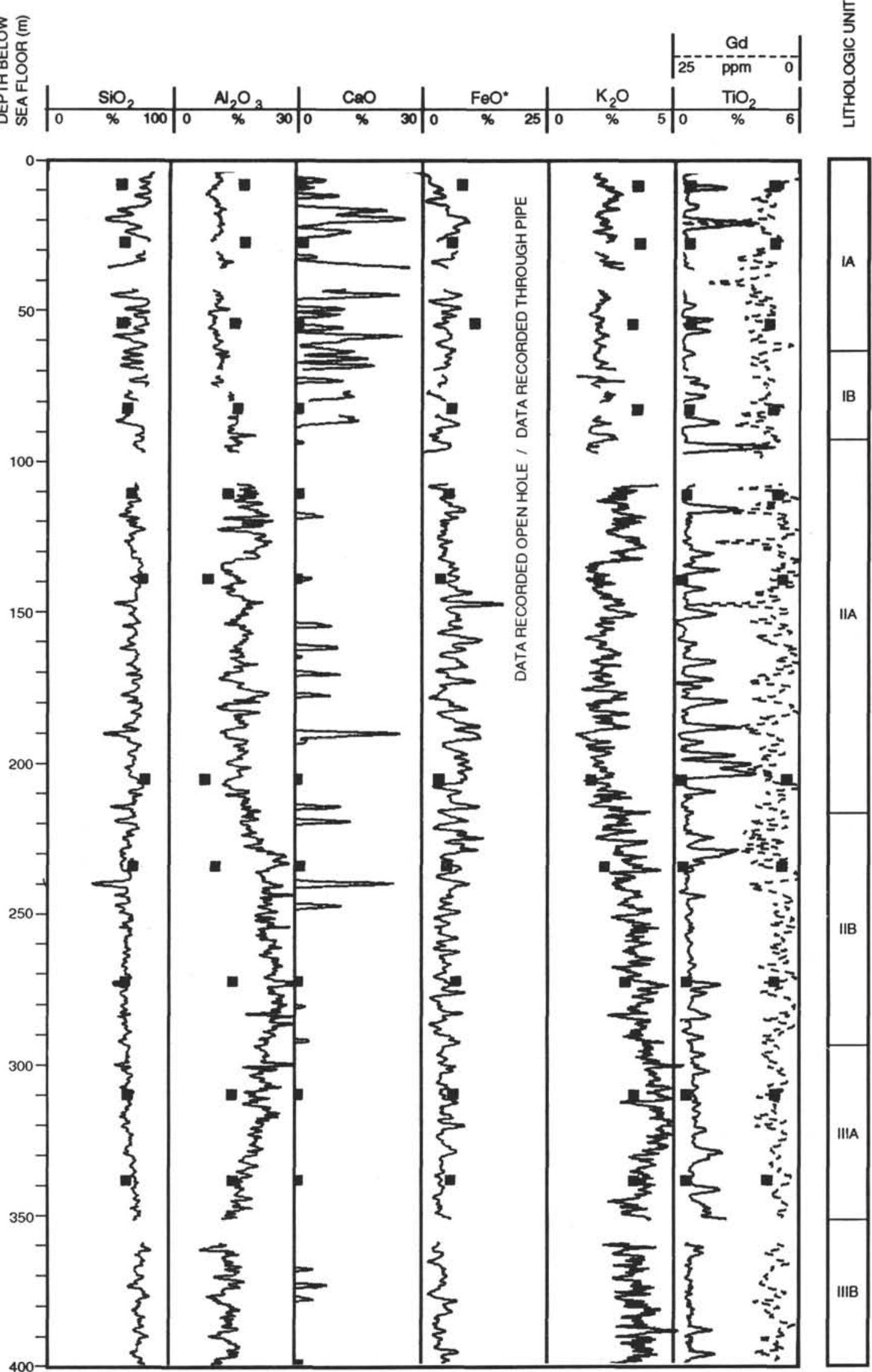

Figure 5. Estimates of the major oxide weight fractions from geochemical logs at Hole 794B. Squares represent XRF results from cores (R.W. Murray, pers. comm., 1991). 


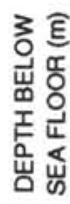

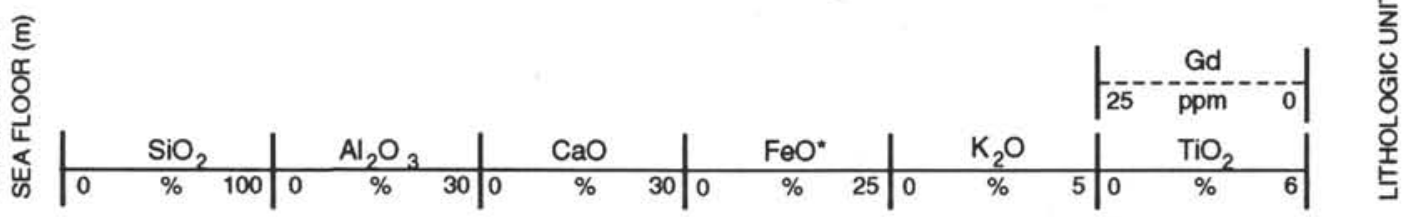
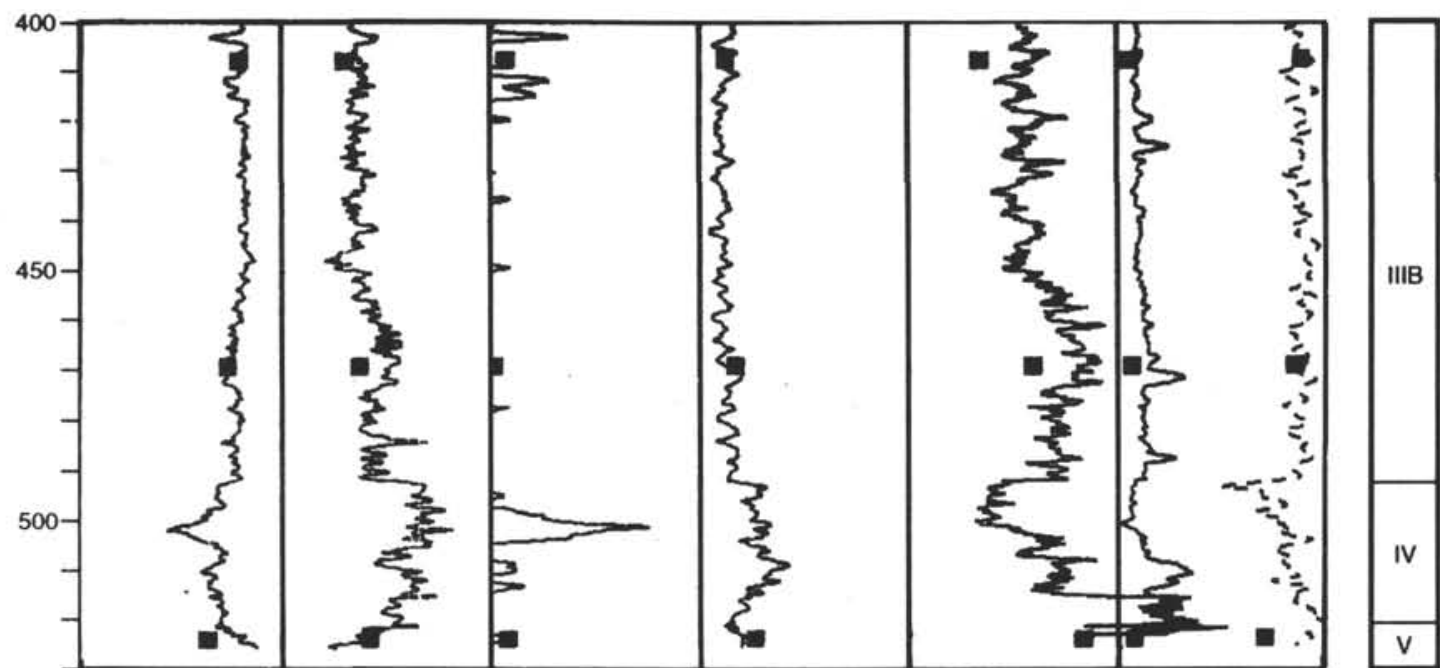

Figure 5 (continued). 

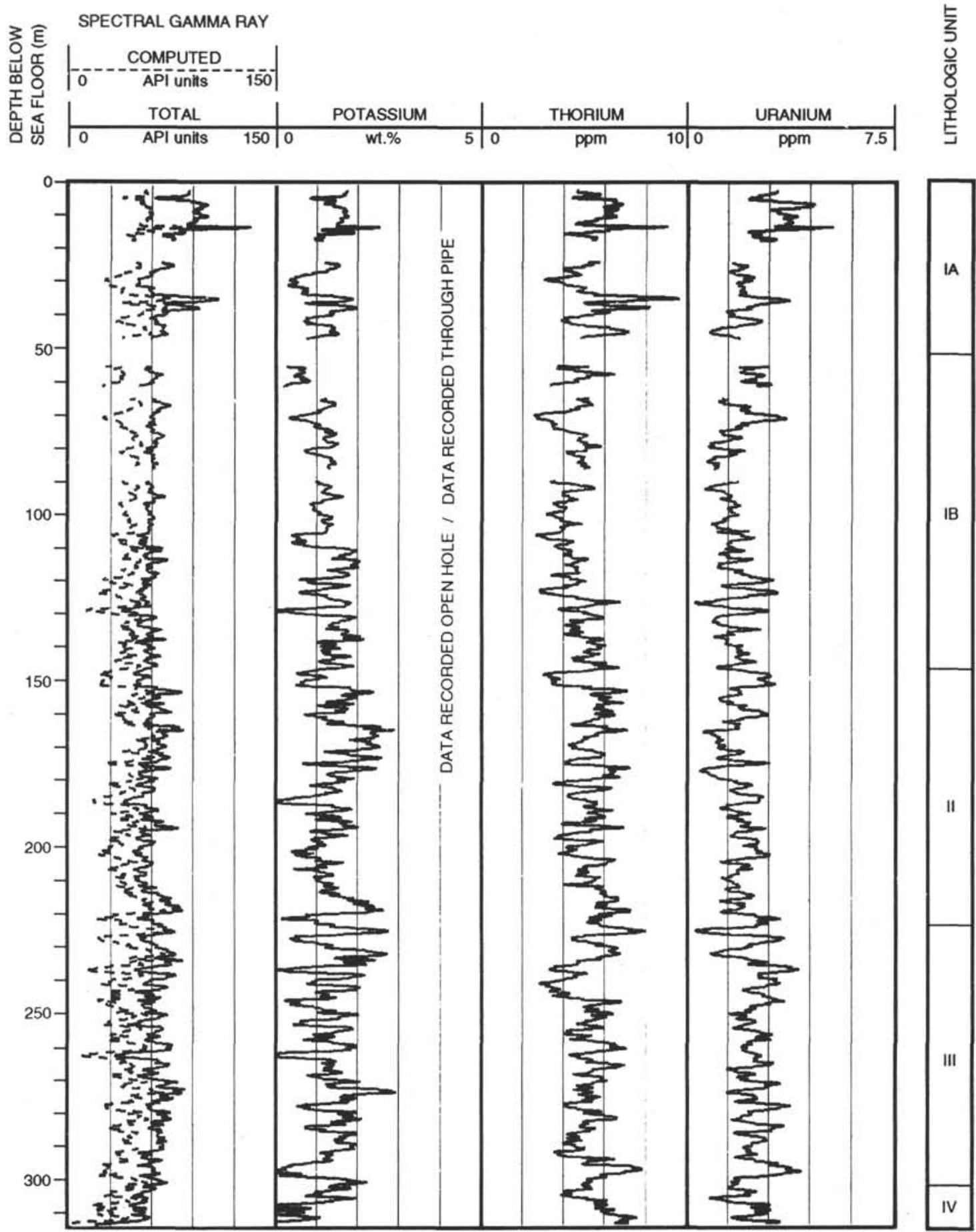

Hole 796B: legend of lithologic units

Unit IA. Diatom-bearing clay and silty clay

Unit IB. Clay and silty clay with frequent sand beds

Unit II. Clayey diatom ooze and diatom claystone

Unit III. Siliceous claystone, claystone, and sandstone

Unit IV. Siliceous claystone, pebbly claystone, tuffaceous sandstone, and tuff

Figure 6. Processed natural gamma-ray data at Hole 796B. The large spikes below $545 \mathrm{mbsf}$ are due to tool activation of the formation. To use the $\mathrm{K} \log$ in the normalization process, interpolation was used to eliminate these spikes. 
窟

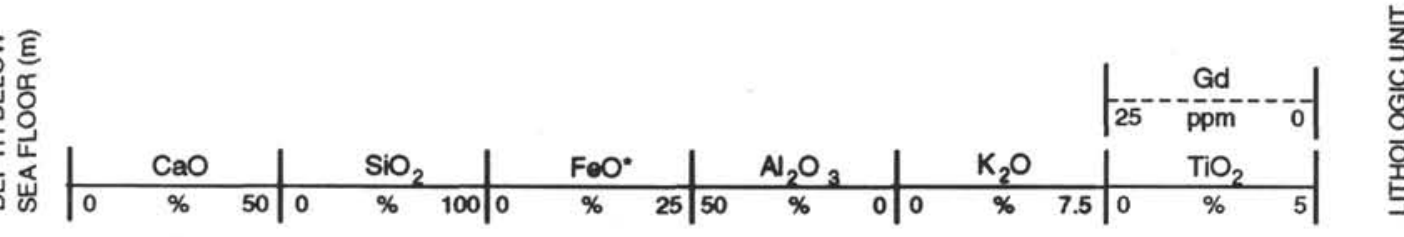

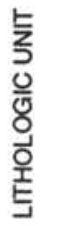

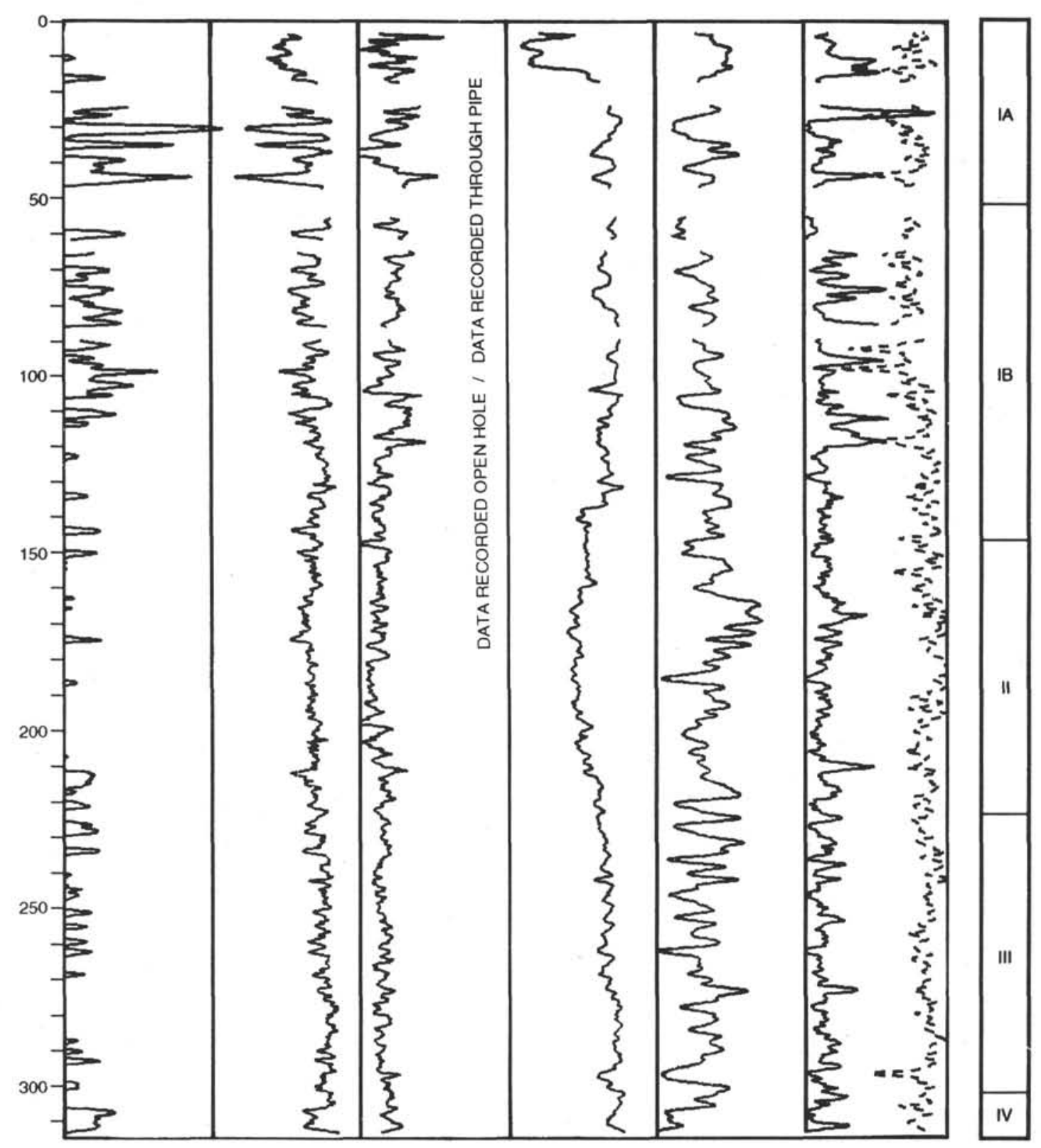

Figure 7. Estimates of the major oxide weight fractions from geochemical logs in Hole 796B. 

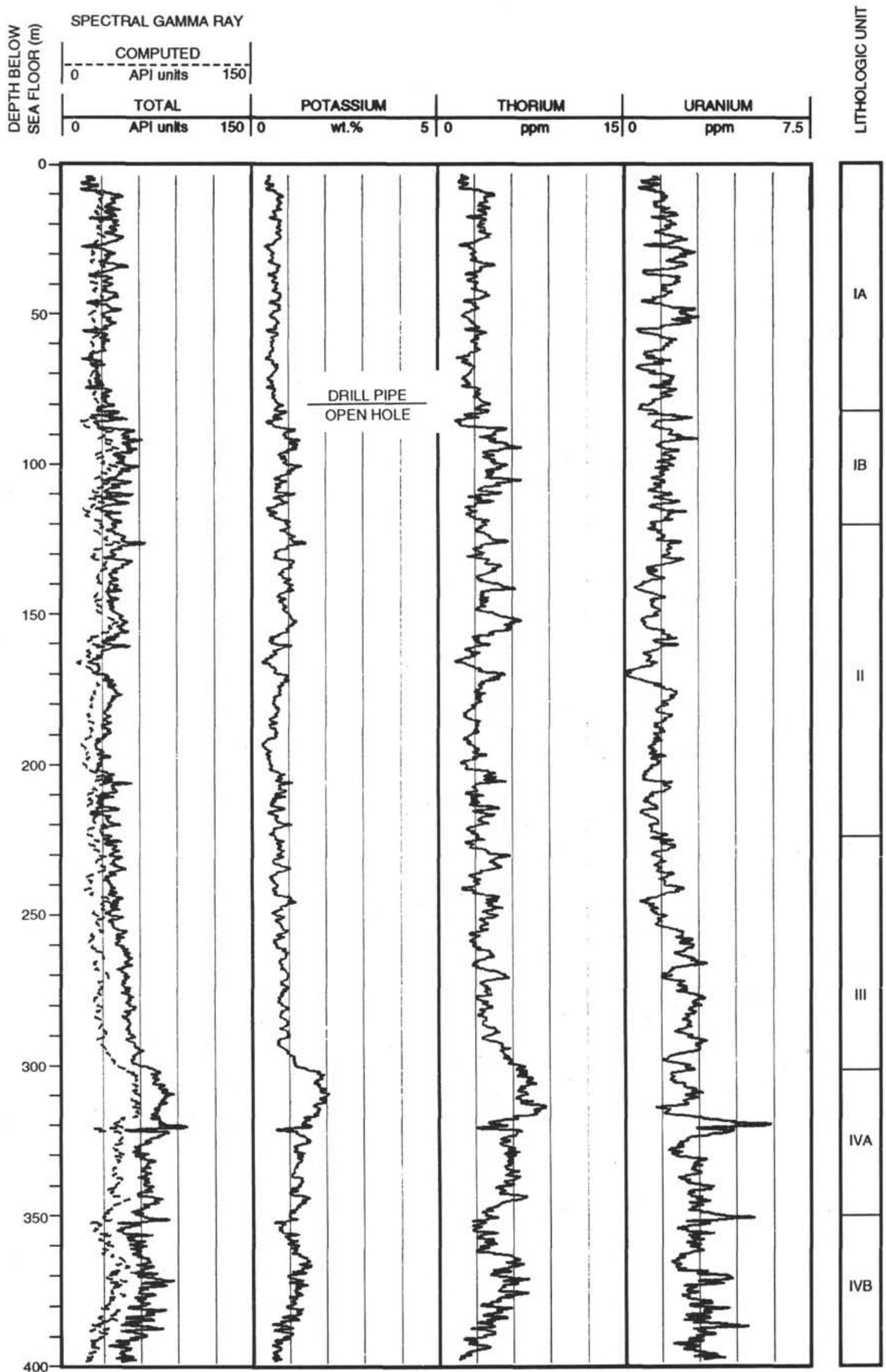

Figure 8. Processed natural gamma-ray data at Hole 797C. 

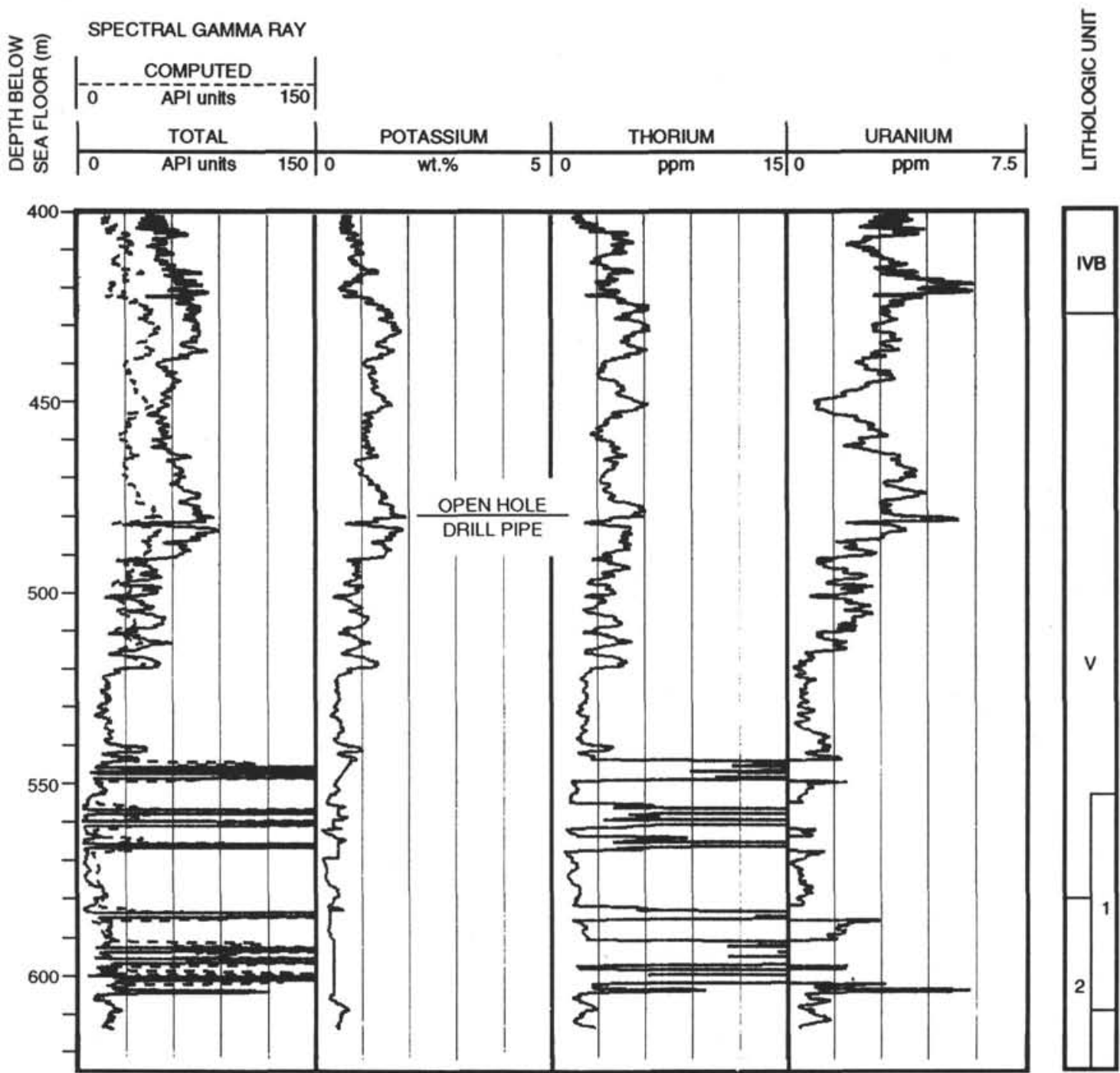

Hole 797C: legend of lithologic units

Sedimentary units

Unit IA. Clay and silty clay

Unit IB. Diatom-bearing ashy clay and silty clay

Unit II. Diatom clay and clayey diatom ooze

Unit III. Diatom clay, silty claystone, and diatom ooze

Unit IVA. Claystone and silty claystone with intercalations of chert

Unit IVB. Siliceous claystone, claystone, and chert

Unit V. Siliceous claystone, phosphatic and calcareous claystone, and tuff

Igneous units

Unit 1. Aphyric and sparsely plagioclase olivine phyric basaltsinterbedded with sediments of Unit $\mathrm{V}$

Unit 2. Highly altered aphyric and sparsely plagioclase olivine phyric basalts and dolerite interlayered with sediments of Unit V. 


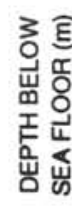
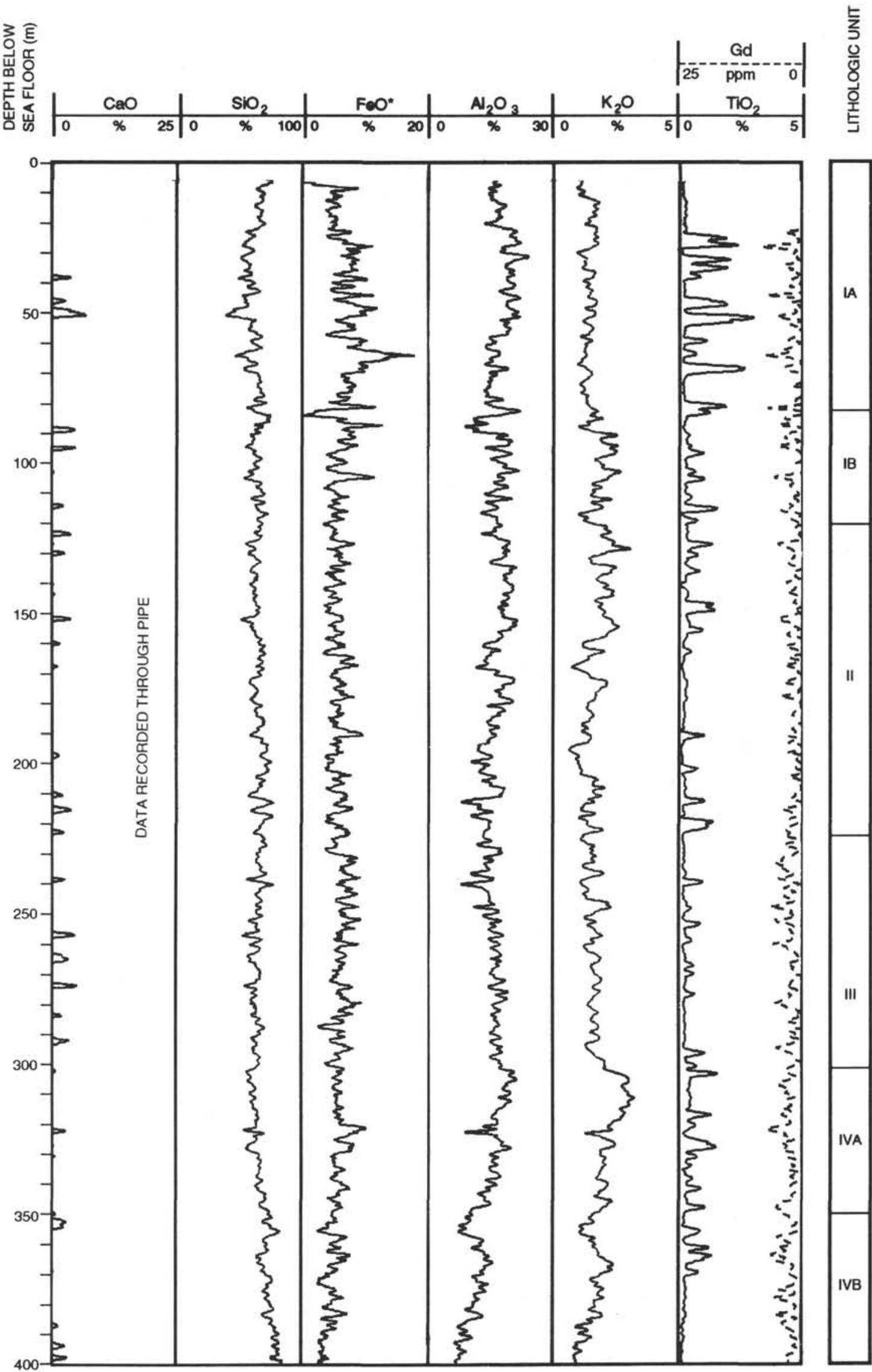

Figure 9. Major oxide weight fractions from geochemical logs in Hole 797C compared to XRF results from core (Tamaki, Pisciotto, Allan, et al., 1990). 


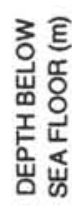
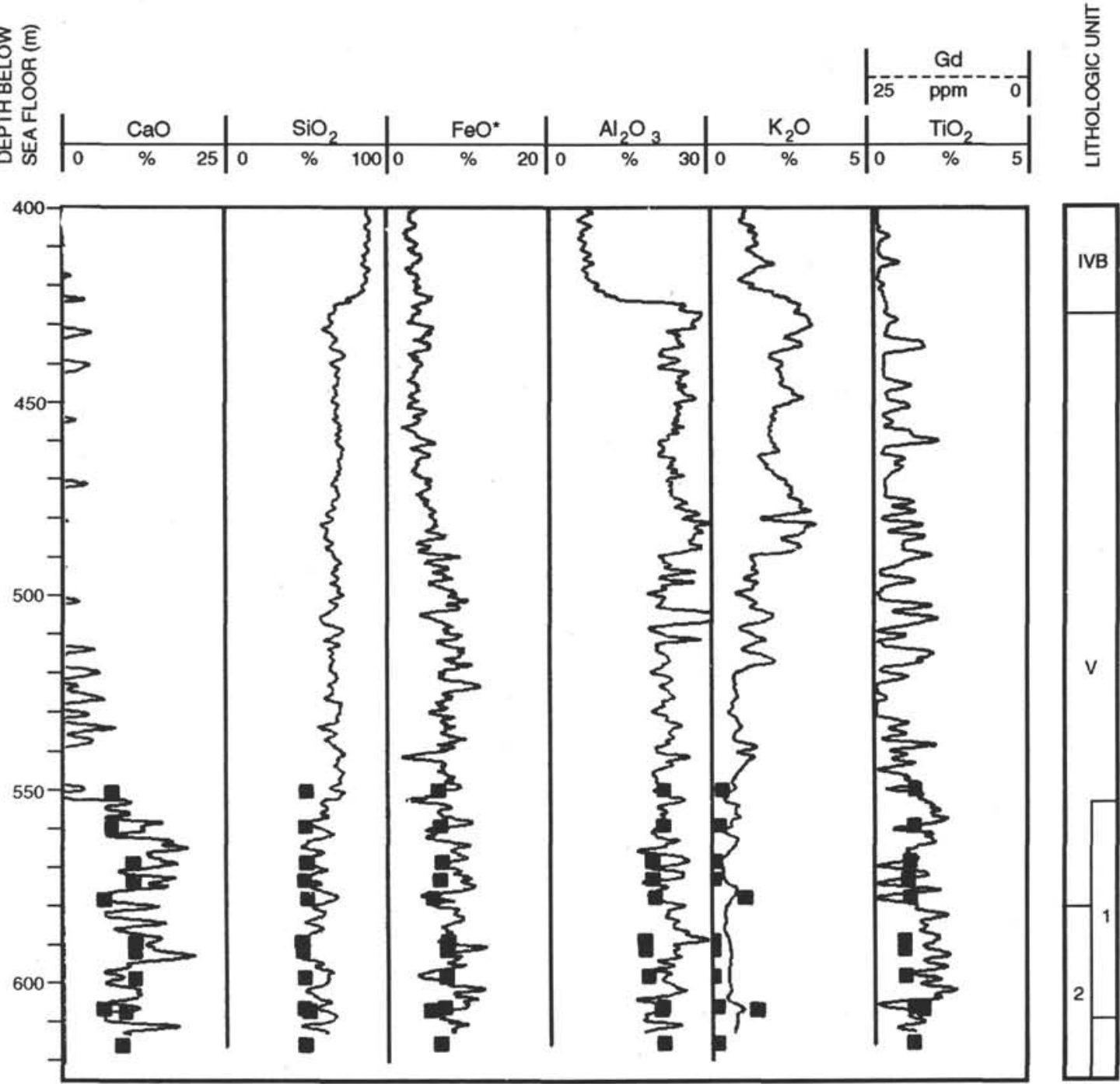

Figure 9 (continued). 